\title{
The Distribution of Iron in Iron-deficient Toxin-synthesizing and in Excess-iron Non-toxin-synthesizing Corynebacterium diphtheriae
}

\author{
By R. C. RIGHELATO* \\ Rijks Instituut voor de Volksgezondheid, Sterrenbos, I, Utrecht, \\ The Netherlands
}

(Accepted for publication II July I969)

SUMMARY

In the presence of excess iron diphtherial toxin was not produced by Corynebacterium diphtheriae $\mathrm{CN} 2000$. $2 \cdot 8 \%$ of the intracellular iron was present in the soluble fraction of washed bacteria; the remainder was bound on the respiratory particles, $4 \%$ as haeme and the rest as non-haeme iron. Succinate but not NADH reduced the cytochromes and a small proportion of the non-haeme iron.

Toxin was synthesized at a high rate by bacteria containing $6.5 \%$ of the iron present in excess-iron bacteria. Under such iron-deficient conditions the iron-containing components of the respiratory particles were present in decreased quantities. NADH oxidation, which proceeded via a soluble flavoprotein, was not affected by iron-deficiency, nor could reduction of non-haeme iron by NADH be demonstrated. The transition between the iron-deficient and the excess-iron states was studied.

\section{INTRODUCTION}

Diphtherial toxin is released by Corynebacterium diphtheriae PW 8 (PD) in large quantities only when iron is exhausted from the medium (Pappenheimer, 1955); under such conditions, growth of the bacteria occurs without increase in the concentration of some iron-containing enzymes (Righelato \& van Hemert, 1969). Addition of $90 \mu \mathrm{g}$. atom $\mathrm{Fe} / \mathrm{l}$. to the culture medium immediately completely and specifically inhibited toxin release. Edwards \& Seamer (1960) found that iron in the medium up to $60 \mu \mathrm{g}$. atom/l. was almost entirely taken up by the bacteria, and Yoneda \& Ishihara (1960) showed that iron was readily bound by iron-deficient $C$. diphtheriae organisms, no detectable extraction being observed on repeated washing with buffer at pH 6.8. Treatment with $10 \%(\mathrm{w} / \mathrm{v})$ dithionite released almost all of the bacteria-bound iron. These authors did not, however, investigate the iron bound as haeme. Moreover, the location of iron within the cell has not been investigated in detail. It is known that addition of iron to iron-deficient toxin-producing cultures of the PW 8 strain results in an increase in the concentrations of catalase and cytochrome in addition to the inhibition of toxin and coproporphyrin release (Pappenheimer \& Hendee, 1947). These observations led to the hypothesis that the toxin was an apoenzyme of diphtherial cytochrome $b$ (Pappenheimer, 1947). More recently it has been found that the electron transport pathways of the PW 8 (PD) strain differ from those of other strains

\footnotetext{
* Present address: Glaxo Laboratories Limited, Ulverston, Lancs.
} 
of $C$. diphtheriae which produce less toxin (Pappenheimer, Howland \& Miller, 1962). The present work investigates the distribution and function of haeme iron and nonhaeme iron in iron-deficient toxinogenic bacteria and in bacteria whose toxin release has been inhibited by growth in excess of iron.

\section{METHODS}

Organism. Corynebacterium diphtheriae CN2000 was used; it has been identified as a PW $8_{S}(\mathrm{PD})$ strain (Barksdale, Garmise \& Rivera, I96I) by Professor W. L. Barksdale.

Culture, media and apparatus are those described by Righelato \& van Hemert (1969) for glucose-limited continuous culture of $C$. diphtheriae.

Preparation of bacterial extracts. Bacteria were harvested from cultures, by centrifugation for $20 \mathrm{~min}$. at $8000 \mathrm{~g}$, washed twice in $0.05 \mathrm{M}$-phosphate $(\mathrm{pH} \mathrm{7.3)}$ and resuspended in the buffer at ro times the concentration of the cultures. For all assays the concentrated bacterial suspension was treated in a $20 \mathrm{Kc} / \mathrm{s}$ MSE sonic oscillator for $30 \mathrm{~min}$. The broken-cell suspension so produced was used for determination of the quantities of protein, iron, cytochrome $b$, catalase and succinate dehydrogenase. All operations were done at o to $5^{\circ}$.

Bacterial protein was measured by the biuret method of Stickland (I95I).

Respiratory assays. NADH oxidase and succinate oxidase were measured by the oxygen uptake rate at $150 \mathrm{~mm}$. $\mathrm{Hg}$ oxygen partial pressure in an oxygen-electrode cell (Rank Ltd., Cambridge) at $35^{\circ}$.

The broken-cell suspension exhibited a high endogenous metabolism. Removal of whole bacteria by centrifugation at $3000 \mathrm{~g}$ for Io min. followed by passage over G50 Sephadex almost eliminated the endogenous metabolism, whilst 80 to $90 \%$ of the protein, iron and catalase and succinic dehydrogenase activities was recovered.

Total haeme was extracted with $\mathrm{HCl}+$ acetone and measured as the pyridine hemochrome (Jacobs \& Wolin, I963).

Cytochrome $b$ concentration in the disrupted bacteria was measured by dithionitereduced minus ferricyanide-oxidized difference spectra, on a Beckman DB spectrophotometer. The difference between the $559 \mathrm{~m} \mu$ peak and the $577 \mathrm{~m} \mu$ trough was recorded and an $\mathrm{mM}$ extinction coefficient of $28.5 \mathrm{~cm} . .^{-1}$ found for mitochondrial cytochrome $b$, was used in estimating cytochrome $b$ haeme concentrations (Rieske, I967). The bacterial concentration used for this assay was equiv. 5 to $10 \mathrm{mg}$. bacterial protein $/ \mathrm{ml}$.

Succinate dehydrogenase (succinate-ferricyanide oxido-reductase) activity was measured by the method of Pappenheimer et al. (1962).

Catalase activity was measured by the method of Herbert (1955). Catalase haeme was calculated from the activity, assuming four haeme groups/mole, mol. wt of $2 \cdot 3 \times$ $10^{5}$, and an activity of pure catalase $5.3 \times 10^{7} / \mathrm{M} / \mathrm{sec}$. (White, 1962 ).

Iron assays. The iron content of the medium and of disrupted bacteria was measured by the method of Kurup \& Brodie (1967a). Samples (2 ml.) of disrupted bacteria ( 5 to $10 \mathrm{mg}$. protein $/ \mathrm{ml}$.) were put in two matched cuvettes, one oxidized with $0.05 \mathrm{ml}$. $0 \cdot \mathrm{I} \mathrm{M}-\mathrm{K}_{3} \mathrm{Fe}(\mathrm{CN})_{6}$ and the other reduced by the addition of a few $\mathrm{mg}$. dithionite; the difference spectrum between $560 \mathrm{~m} \mu$ and $480 \mathrm{~m} \mu$ was recorded. One-tenth $\mathrm{ml} .40 \mathrm{~mm}$ $o$-phenanthroline in $10 \%(\mathrm{w} / \mathrm{v})$ ethanol in water was added to each cuvette. After rotating to mix and standing for $5 \mathrm{~min}$. the difference spectrum was taken again; a 
peak at 5 IO $\mathrm{m} \mu$ corresponded to the ferrous-o-phenanthroline complex. A millimolar extinction coefficient of $7.9 \mathrm{~cm}^{-1}$ was used to calculate iron concentration.

Coproporphyrin in the cultures fluid was adsorbed on calcium phosphate, washed, eluted with $0.5 \mathrm{~N}-\mathrm{HCl}$ and measured spectrophotometrically (Falk, 1964).

\section{RESULTS}

For the production of significant quantities of toxin in glucose-limited chemostat cultures of Corynebacterium diphtheriae $\mathrm{CN} 2000$ an intracellular iron concentration of less than $2 \cdot 7 \mu \mathrm{g}$. atom/g. bacterial protein was necessary (Righelato \& van Hemert, I969); 0.IO g. toxin protein/g. bacterial protein were obtained in glucose-limited chemostat cultures when the intracellular iron concentration was about $\mathrm{I} \cdot 0 \mu \mathrm{g}$. atom/g. bacterial protein. The addition of $90 \mu \mathrm{g}$. atom $\mathrm{Fe} / 1$. to such a culture resulted in complete and immediate inhibition of toxin release.

When a high concentration of iron was added to a chemostat culture supplied with a low iron medium the iron was rapidly taken up by the bacteria (Fig. I). Within Io min. of adding iron an increase in the non-haeme iron content of the bacteria was observed and a maximum intracellular concentration was reached within 90 min. at which time $20 \%$ of the iron in the medium remained in the culture supernatant fluid.

Table 1 . The effect of iron on toxin and porphyrin release and on intracellular iron concentrations in steady-state glucose-limited chemostat cultures of Corynebacterium diphtheriae CN 2000

Fe in medium ( $\mu$ g. atom/l.)

Intracellular non-haeme $\mathrm{Fe}(\mu \mathrm{g}$. atom/g bacterial protein)

Intracellular haeme $\mathrm{Fe}$ ( $\mu$ mole/g. bacterial protein)

7

97

Extracellular coproporphyrin ( $\mu \mathrm{mol} / \mathrm{g}$. bacterial protein)

Extracellular toxin ( $\mu$ mole/g. bacterial protein)

$\begin{array}{ll}I .03 & 15 \\ 0.16 & 0.58 \\ I .67 & 0.38 \\ I .5 I & 0\end{array}$

* Calculated from the value $2 \cdot 44 \mu \mathrm{g}$. protein/Lf and assuming a molecular weight of 64,500 (Relyveld et al. 1964).

Table I shows the effect of the excess iron concentration in the medium on the steady-state intracellular haeme and non-haeme iron concentrations, and on toxin and coproporphyrin syntheses, both of which are known to be inhibited by iron (Pappenheimer \& Hendee, 1947). Of the iron taken up by the restricted-iron toxinsynthesising bacteria $13 \%$ was recovered as haeme. At the high iron concentration, although the total haeme content of the bacteria increased 3.5 -fold it constituted only $3.7 \%$ of the bacterial iron, a greater proportion of the iron being recovered as nonhaeme iron. It is clear from Table $I$ that the inhibition of coproporphyrin release cannot simply be accounted for by the channelling of coproporphyrinogen to protoporphyrin IX which is incorporated into haeme.

Iron is involved in many oxidation-reduction reactions in the cell, particularly in the respiratory enzymes, as both haeme and non-haeme iron. It was shown by Righelato \& van Hemert (1969) that the concentrations of two haeme-containing enzymes and succinate dehydrogenase, which contains non-haeme iron, are limited in the medium used for toxin production by Corynebacterium diphtheriae. Table 2 shows the activities 
Table 2. The effect of iron on the concentration of some respiratory enzymes of Corynebacterium diphtheriae CN2000

\begin{tabular}{|c|c|c|c|c|}
\hline & & \multicolumn{2}{|c|}{$\begin{array}{l}\text { Fe in medium } \\
(\mu \mathrm{g} . \text { atoms } / 1 .\end{array}$} & \multirow{2}{*}{$\begin{array}{c}\text { Fe-deficient } / \\
\text { Fe-excess }(\%)\end{array}$} \\
\hline & & 7 & 97 & \\
\hline $\begin{array}{l}\text { Succinate oxidase activity } \\
\text { Succinate dehydrogenase activity } \\
\text { NADH oxidase activity }\end{array}$ & \} $\begin{array}{c}(\mu \text { mole } / \text { g. bacterial } \\
\text { protein } / \mathrm{min} .)\end{array}$ & $\begin{array}{c}3 \cdot 4 \\
50 \\
3 \cdot 8\end{array}$ & $\begin{array}{r}8 \cdot 3 \\
152 \\
4 \cdot 5\end{array}$ & $\begin{array}{l}41 \\
33 \\
84\end{array}$ \\
\hline $\begin{array}{l}\text { Catalase haeme concentration } \\
\text { Cytochrome } b \text { haeme concentratio }\end{array}$ & \}$_{\text {protein })}^{(\mu \text { mole/g. bacterial }}$ & $\begin{array}{l}0.0021 \\
0.10\end{array}$ & $\begin{array}{l}0.020 \\
0.31\end{array}$ & $\begin{array}{l}10 \cdot 5 \\
32\end{array}$ \\
\hline
\end{tabular}

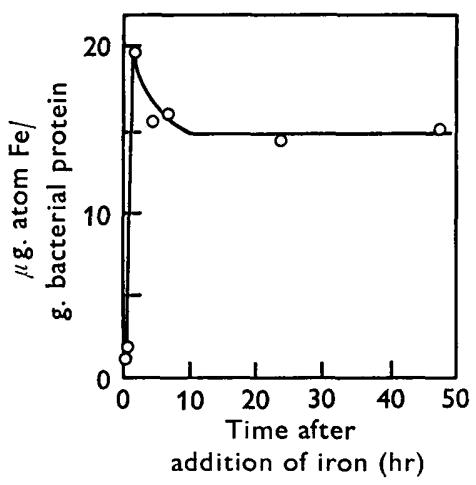

Fig. I
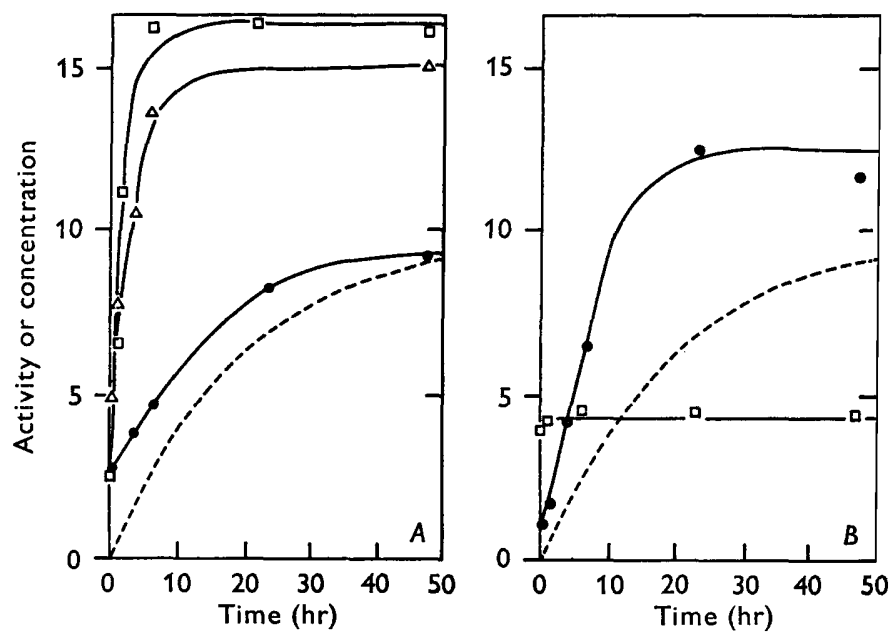

Fig• 2

Fig. I. The uptake of iron by iron-deficient Corynebacterium diphtheriae $\mathrm{CN} 2000$. At o hr the iron concentration in a steady-state glucose-limited chemostat culture was raised from 7 to 97 $\mu \mathrm{g}$. atom/l. The culture contained $3.85 \mathrm{~g}$. bacterial protein $/ 1$. Dilution rate $=0.05 \mathrm{I} \mathrm{hr}^{-1}$.

Fig. 2. The effect of iron addition to iron-deficient Corynebacterium diphtheriae $\mathrm{CN} 2000$ on the concentrations of some respiratory enzymes. At o hr the iron concentration in a steadystate glucose-limited chemostat culture was raised from 7 to $97 \mu \mathrm{g}$. atom/1. The culture contained $3.85 \mathrm{~g}$. bacterial protein/l. Dilution rate $=0.05 \mathrm{I} \mathrm{hr}^{-1} . A$. Components of the particulate fraction: $\square$, Succinate oxidase, $\mu$ mole succinate/g. bacterial protein $/$ min.; $\triangle$, succinate ehydrogenase, $\mu$ mole succinate/g. bacterial protein/min.; 9 , cytochrome $b$, absorbtion $/ g$. bacterial protein $\times$ ro. $B$. Components of the soluble fraction: $\square$, NADH oxidase, $\mu$ mole NADH $/ g$. bacterial protein/min.; 9 , catalase haeme, $\mu$ mole/g. bacterial protein $\times 500$. The net synthesis of bacterial protein after the addition of iron is shown by the broken line. It was calculated from the expression $1-e^{-D t}$, where $D$ is the dilution rate of the culture and $t$ the time since addition of iron. It is a measure of new growth and does not take into account protein turnover. (mg. new protein/mg. protein $\times$ IO).

of two respiratory processes and the concentrations of two haeme-containing enzymes in the steady-state chemostat cultures at low and high iron concentrations. With the exception of the NADH oxidase system, a soluble flavoprotein in the PW 8 (PD) strain (Pappenheimer et al. 1962), large increases were observed in all the enzymes measured. Smaller quantities of cytochromes $c$ and $a$ were also present in the bacteria and 
increased after addition of iron (see below, Fig. 3). Thus in the toxin-producing iron-restricted bacteria the concentrations of the cytochromes, catalase and succinate dehydrogenase appear to be limited by the low iron concentration.

The rates at which the concentrations of the enzymes shown in Table 2 changed after addition of iron to a steady-state glucose-limited chemostat culture are compared in Fig. 2 with the quantity of bacterial protein in the culture synthesised after the addition of iron. Succinate dehydrogenase and succinate oxidase increased most rapidly and approximately in parallel, suggesting that succinate oxidation was ratelimited by the dehydrogenase step, rather than by the oxidation of the cytochrome(s) involved. Cytochrome $b$ increased in concentration approximately in parallel with new growth, whilst catalase concentration increased at a rate intermediate between that of cytochrome $b$ and succinate dehydrogenase. The NADH oxidase system showed very little change after addition of iron.

The distribution of iron in the bacteria was investigated by differential centrifugation of the disrupted bacteria. After removal of unbroken bacteria and other heavy material by centrifugation at $3000 \mathrm{~g}$ for $10 \mathrm{~min}$. the suspension was centrifuged at $\mathrm{I} 20,000 \mathrm{~g}$ for $\mathrm{I} 20 \mathrm{~min}$. The supernatant fluid from this centrifugation is termed the soluble fraction (S) and the deposit, after twice washing in buffer, the particulate fraction (P).

Table 3. The distribution of haeme and non-haeme iron in subcellular fractions of Corynebacterium diphtheriae $\mathrm{CN} 2000$ from glucose-limited chemostat cultures in restricted-iron and excess-iron media

\begin{tabular}{|c|c|c|c|c|}
\hline \multicolumn{2}{|c|}{ Bacterial fraction } & $\begin{array}{l}\text { Fe-restricted } \\
(7 \mu \mathrm{g} . \text { atom } / 1 \text {. }\end{array}$ & $7 \mu \mathrm{g}$. ato & $\begin{array}{l}\text { as \% } \\
\text { excess }\end{array}$ \\
\hline Broken bacteria & & & & \\
\hline Non-haeme iron & & $1 \cdot 03$ & 15 & \\
\hline Total haeme iron & & 0.16 & 0.58 & 28 \\
\hline Catalase haeme iron & & 0.0021 & 0.020 & 10 \\
\hline Soluble fraction & & & & \\
\hline Non-haeme iron & $\mu$ g. atom $\mathrm{Fe} / \mathrm{g}$. & 0.28 & 0.44 & 62 \\
\hline Total haeme iron & bacterial protein & & ND & 一 \\
\hline Catalase haeme iron & & 0.0021 & 0.020 & IO \\
\hline Respiratory particles $\left(\mathrm{P}_{\mathrm{B}}\right)^{*}$ & & & & \\
\hline Non-haeme iron & & 0.65 & 16 & 4 \\
\hline Total haeme iron & & 0.15 & 0.49 & 30 \\
\hline Catalase haeme iron & & ND & ND & - \\
\hline
\end{tabular}

* The ratio of cytochrome $b$ in the broken bacteria to the cytochrome $b$ in the $\mathbf{P}_{\mathrm{B}}$ fraction was used to calculate the amount of particle-bound iron in the bacteria:

$$
\mathrm{Fe}(\text { Bacteria })=F e\left(\mathrm{P}_{\mathrm{R}}\right) \times \frac{\text { Cyt. } b \text { (bacteria) }}{\text { Cyt } b\left(\mathrm{P}_{\mathrm{R}}\right)} .
$$

The soluble fraction contained 90 to $100 \%$ of the catalase activity of the whole bacterial preparation, indicating a high degree of disruption of the bacteria by the ultrasonic treatment. The fraction contained no dithionite-reducible haeme though small amounts of haeme were present as catalase. There was a low concentration of non-haeme iron in the preparations from both iron-resistricted and excess-iron bacteria (Table 3). No reduction of the non-heme iron by succinate and by NADH was detectable by the method of Kurup \& Brodie (1967b), though NADH brought about reduction of a soluble flavoprotein. Pappenheimer et al. (1962) suggested that a soluble 
flavoprotein was responsible for NADH oxidation in the PW 8 (PD) strain of Corynebacterium diphtheriae, since NADH dehydrogenase activity was restricted to the soluble fraction.

The greater part of the non-haeme iron present in the bacteria was recovered in the particulate fraction $P$ which also contained 70 to $90 \%$ of the cytochromes and succinate dehydrogenase after two washes in $0.05 \mathrm{M}$-phosphate $(\mathrm{pH} 7.5)$. By centrifugation of a suspension of the $P$ fraction at $80,000 \mathrm{~g}$ for $90 \mathrm{~min}$. a suspension of the repiratory particles $\left(P_{R}\right)$ was obtained, although not all of the cytochrome could be extracted from the $P$ fraction in this way. This suspension, after centrifugation at I20,000 $\mathrm{g}$ for $\mathrm{I} 20 \mathrm{~min}$., gave a homogeneous translucent red pellet. The pellet obtained from the excess-iron bacterial extract had a deeper red colour than that from the

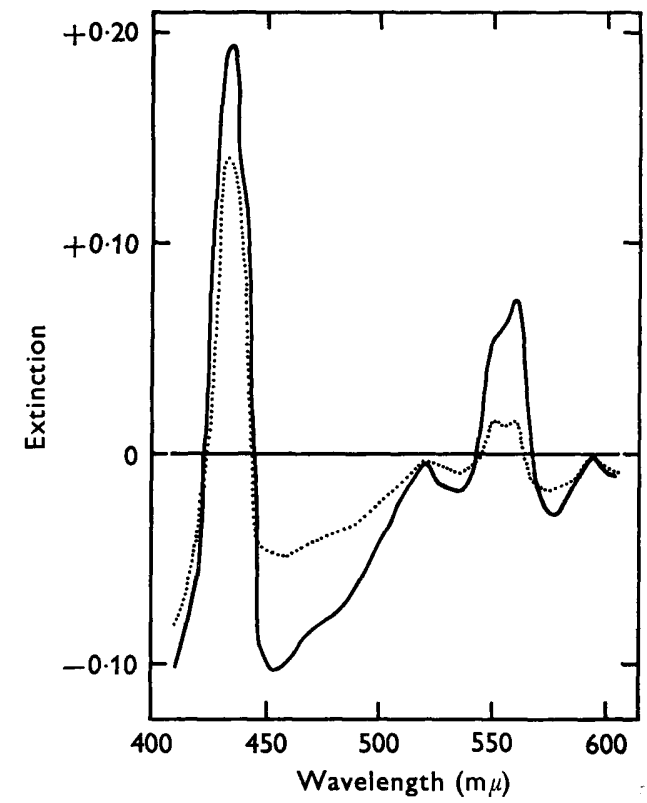

Fig. 3

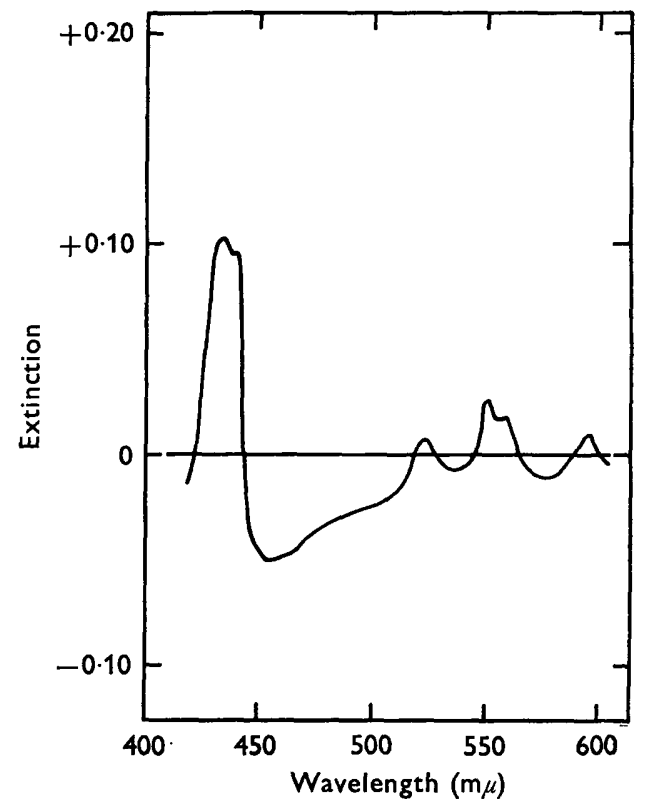

Fig. 4

Fig. 3. Dithionite-reduced minus oxidised difference spectra of the respiratory particle fractions of iron-deficient and excess-iron Corynebacterium diphtheriae $\mathrm{CN} 2000$. Unbroken line, bacteria contained $\mathrm{I} 6 \mu \mathrm{g}$. atom $\mathrm{Fe} / \mathrm{g}$. protein; dotted line, bacteria contained $\mathrm{I} \cdot 2 \mu \mathrm{g}$. atom $\mathrm{Fe} / \mathrm{g}$. protein; zero line, oxidised minus oxidized samples. The reaction mixture contained about $3 \mathrm{mg}$. particle protein $/ \mathrm{ml}$; $\mathrm{PO}_{4}, 0.05 \mathrm{M} ; \mathrm{Mg}, 0.02 \mathrm{M}$; tris, $0.05 \mathrm{M} ; \mathrm{pH} 7.4$. A few mg. sodium dithionite were added to one cuvette. The concentrations of respiratory particles were adjusted to give the quantity of cytochrome $b$ present in Io $\mathrm{mg}$. bacterial protein.

Fig. 4. Succinate-reduced minus oxidized difference spectrum of respiratory particle fraction of Corynebacterium diphtheriae $\mathrm{CN} 2000$. Bacteria contained $16 \mu \mathrm{g}$. atom $\mathrm{Fe} / \mathrm{g}$. protein/ml.; $\mathrm{PO}_{4}, 0.05 \mathrm{M} ; \mathrm{Mg}, 0.02 \mathrm{M}$; tris, 0.05 M; pH 7.4. A few mg. succinate were added to one cuvette at $25^{\circ}$.

iron-restricted bacteria. The concentration of haeme and non-haeme iron in the $P_{R}$ fraction was about three times higher than the $P$ fraction. The ratios of haeme:nonhaeme iron were similar for the $\mathbf{P}$ and $\mathbf{P}_{\mathbf{R}}$ fractions. It was concluded that virtually all 
of the haeme and non-haeme iron present was associated with particles of the type recovered in the $P_{R}$ fraction.

Table 3 shows the distribution of iron in the fractionated bacteria. Clearly the $P_{B}$ fraction was the main site of action of iron, where it was found as both haeme and non-haeme iron. Of the iron taken up by the bacteria grown in excess iron only $4 \%$ was found as haeme whilst about $94 \%$ was firmly bound to the $P_{R}$ fraction as nonhaeme iron.

The $P_{R}$ fraction was obtained fully oxidised after the washing procedure described above. Dithionite-reduced minus oxidised difference spectra showed that the $\mathbf{P}_{\mathbf{R}}$ fraction contained flavoprotein, cytochrome $b_{558}$ and smaller amounts of cytochromes $c_{551}$ and $a$ (Fig. 3). The concentrations of all of the components was higher in the preparations from excess-iron bacteria. Fig. 4 shows the difference spectrum obtained by using succinate to reduce the sample; in this case cytochromes $c_{551}$ and' $a$ were fully reduced but $b_{559}$ was only partially reduced, demonstrating clearly the $c_{551}$ component. Succinate also reduced much of the flavoprotein and $0.7 \%$ of the non-haeme iron. Succinate oxidase activity of the $P_{R}$ fraction was $30 \%$ inhibited by $3 \mathrm{mM} \mathrm{KCN}$. NADH produced no cytochrome difference spectrum, with or without the soluble fraction, nor was there any NADH oxidase activity in the $P_{B}$ fraction.

\section{DISCUSSION}

In the presence of an excess of iron in the medium, giving an intracellular concentration of $15.6 \mu \mathrm{g}$. atom $\mathrm{Fe} / \mathrm{g}$. bacterial protein and an extracellular concentration of $20 \mu \mathrm{g}$. atom/1. medium, diphtheria toxin was not synthesised by Corynebacterium diphtheriae $\mathrm{CN} 2000$ in glucose-limited chemostat culture. Toxin was released at a high rate when the intracellular iron concentration was $\mathrm{I} \cdot 2 \mu \mathrm{g}$. atom $/ \mathrm{g}$. bacterial protein and the extracellular concentration $0.5 \mu \mathrm{g}$. atom/l. Of the extra iron present in the excess-iron bacteria $97 \%$ was firmly bound to the respiratory particles, $3 \%$ as haeme and the rest as non-haeme iron. Concentrations of particle-bound non-haeme iron similar to those found in the present work with $C$. diphtheriae, have been found on the respiratory particles of Mycobacterium phlei, apparently bound to thiol groups (Kurup $\&$ Brodie, $1967 a$ ). The function of the non-haeme iron is not clear; $0.7 \%$ was reducible by succinate, whilst $30 \%$ of the cytochrome $b$, a similar proportion of the flavin, and most of the cytochrome $c$ and $a / a_{3}$ components were reduced.

The rapid increase of succinate dehydrogenase activity after adding iron to a restricted-iron culture (Fig. 2) may indicate that the enzyme was iron-deficient. The increase in activity may have resulted from the attachment of iron to the enzyme, since the activity of succinate dehydrogenase as measured by ferricyanide reduction is related to the iron content of the enzyme (Singer, Kearney \& Massey, 1957). After addition of iron to an iron-deficient culture the cytochrome concentration increased slowly, approximately in parallel with the bacterial growth. So, although the cytochromes and succinate dehydrogenase are probably located together as a functional group on the respiratory particles, the mechanisms of their limitation by iron-deficiency appear to be dissimilar.

The particle-bound haeme was mostly present in cytochrome $b_{559}$ with smaller buantities of cytochrome $c_{551}$ and $a / a_{3}$. Succinoxidase activity was $30 \%$ inhibited by $3 \mathrm{~mm}-\mathrm{KCN}$, suggesting that a terminal oxidase in addition to cytochrome oxidase was 
involved, perhaps cytochrome $b$. Pappenheimer et al. (1962) found that cytochrome $b_{559}$ acted as a terminal oxidase during succinate oxidation in the PW 8 (PD) strain they used; however, their strain lacked cytochrome $c$.

NADH oxidation was not linked to the respiratory particles but proceeded via a soluble flavoprotein without the reduction of measurable quantities of non-haeme iron. NADH oxidase activities were similar in both restricted-iron and excess-iron bacteria. Thus the involvement of iron in this activity has not been demonstrated.

Jacobs, Maclosky \& Jacobs (1967) studied the inhibition of haeme synthesis in Staphylococcus epidermidis in the absence of molecular oxygen which is required for the oxidation of coproporphyrinogen to protoporphyrin. On exposure of the staphylococci to oxygen in the presence of chloramphenicol rapid large increases in catalase and respiratory activity were observed. Jacobs et al. (1967) concluded that the apoenzymes of the haeme-containing enzymes were synthesized in the absence of haeme. The suggestion that the diphtherial toxin protein, released under conditions of irondeficiency, is, in the presence of excess iron, bound to a respiratory enzyme was first put forward by Pappenheimer (1947). There is also some evidence that toxin is released from the membrane fraction (which includes the respiratory particles) of the iron-deficient bacteria (Uchida \& Yoneda, 1967). Whilst the present work offers no direct evidence for the above theory, the main site of action of iron has been shown to be the respiratory particles and the concentrations of particle-bound iron and the flavin and haeme components have been shown to be effected by iron-deficiency.

This work was done whilst I was a NATO Research Fellow at the Dutch Institute of Public Health. I am indebted to the Direction and Staff of the Institute for their assistance and the facilities which they freely made available and also to the NATO Research Fellowship Scheme.

\section{REFERENCES}

Barksdale, W. L., Garmise, L. \& RIVERA, R. (196I). Toxinogeny in Corynebacterium diphtheriae. J. Bact. 8r, 527.

Edwards, D. C. \& Seamer, P. A. (1960). The uptake of iron by Corynebacterium diphtheriae growing in submerged culture. J. gen. Microbiol. 22, 705.

FALK, J. E. (1964) Porphyrins and Metalloporphyrins. B.B.A. Library, Vol. 2, p. I68. Amsterdam: Elsevier.

Herbert, D. (1955). Catalase from bacteria (Micrococcus lysodeikticus) Meth. Enzymol. 2, 784.

JACOBS, N. J. \& Wolin, M. J. (1963). Electron transport systems of Vibrio succinogenes. I. Enzymes and cytochromes of the electron transport system. Biochim. biophys. Acta 69, 18.

JACOBS, N. J., MACLOSKY, E. R. \& JACOBS, J. M. (1967). Role of oxygen and heme insynthesis and the development of hemoprotein activity in an anaerobically-grown staphylococcus. Biochim. biophys. Acta 148, 645 .

KURUP, C. K. \& BRODIE, A. F. (1967a). Oxidative phosphorylation in fractionated bacterial systems XXVII. The nature of non-heme iron in Mycobacterium phlei. J. biol. Chem. 242, 2909.

KURUP, C. K. \& BrodIE, A. F. (1967b). Oxidative phosphorylation in fractionated bacterial systems XXIX. The involvement of non-heme iron in the respiratory pathways of Mycobacterium phlei. J. biol. Chem. 242, 5830.

Pappenheimer, A. M. Jun. (1947). Diphtheria toxin. III. A re-investigation of the effect of iron on toxin and porphyrin production. J. biol. Chem. 167, 25I.

Pappenheimer, A. M. Jun. (1955). The pathogenesis of diptheria. Symp. Soc. gen. Microbiol. 5, 40.

PaPpenheimer, A. M. Jun. \& Hendee, E. D. (1947). Diptheria toxin. IV. The iron enzymes of Corynebacterium diphtheriae and their possible relation to diphtheria toxin. J. biol. Chem. I7x, 701 . 
Pappenheimer, A. M. Jun., Howland, J. L. \& Miller, P. A. (1962). Electron transport systems in Corynebacterium diphtheriae. Biochim. biophys. Acta 64, 229.

Relyveld, E. H., Raynaud, M., Bepoldin, O. \& Vais, A. (1964). Préparation de la toxine diphterique pure crystallisée à partir de culture en fermenteur. Annls Inst. Pasteur, Paris 107, 618.

RIESKE, J. S. (1967). The quantitative determination of mitochondrial hemoproteins. Meth. Enzymol. Io, 488 .

Righelato, R. C. \& VAN Hemert, P. A. (1969). Growth and toxin synthesis in batch and chemostat cultures of Corynebacterium diphtheriae. J. gen. Microbiol. 58, 403.

Singer, T. P., Kearney, E. B. \& MASSEY, V. (1957). Newer knowledge of succinic dehydrogenase. Adv. Enzymol, 18, 65.

STICKLAND, L. H. (I95I). The determination of small quantities of bacteria by means of the biuret reaction. J. gen. Microbiol. $5,698$.

UCHIDA, T. \& YONEDA, M. (1967). Evidence for the association of membrane with the site of toxin synthesis in Corynebacterium diphtheriae. Biochim. biophys. Acta 145, 210.

WHITE, D. C. (1962). Cytochrome and catalase patterns during growth of Haemophilus influenza. J. Bact. 83, 85I.

YoNEDA, M. \& IsHiHARA, H. (1960). Studies on the iron-binding site of diphtheria bacilli. I. Quantitative binding of iron by iron-deficient cells of a toxinogenic strain of Corynebacterium diphtheriae. Bikens J. 3, I I. 